\title{
Examining intra-African tourism: A trade theory perspective
}

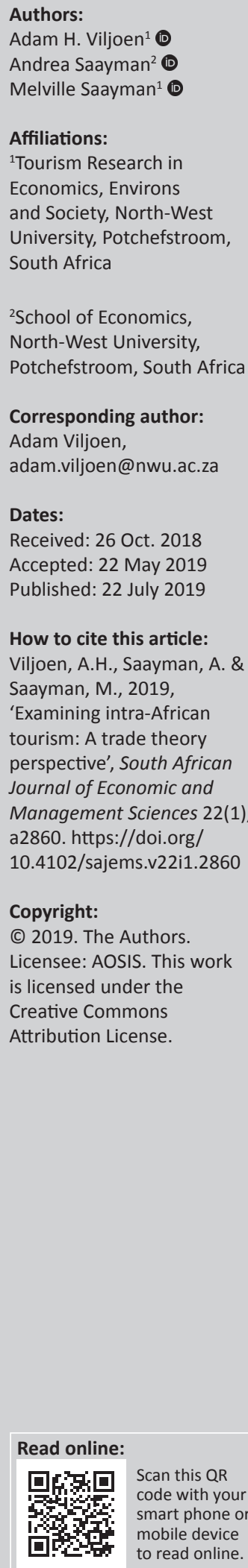

Background: Around the world, domestic and regional travel is considered the backbone of the tourism industry, with as much as $80 \%$ of international visitors within the same region, however, various factors permit or deter tourists to move around freely. The arguments of tourism promoting trade and vice versa, are both valid. Since trade can promote tourism in Africa it implies that regional integration is necessary to foster regional tourism.

Aim: This article seeks to determine whether trade theory is able to explain intra-African tourism. This was done by applying four theoretical models of international trade to bilateral African tourism flows.

Method: Using panel data from 25 African countries over a 10-year period, this research shows that intra-African tourism flows can best be explained by the gravity theory.

Results: Cultural and geographic proximity, as well as the development of the destination country, dictates intra-African tourism. Additionally, African countries that already have an advantage in worldwide tourism receipts also benefit from intra-African tourism.

Conclusion: This research contributes to a greater understanding of the determinants that attract African travellers to other African countries, which holds important implications for both policymakers and destination managers.

Keywords: Intra-African tourism; trade theory; Heckscher-Ohlin model; comparative advantage theory; Linder's hypothesis; gravity model.

\section{Introduction}

Tourism has long been advocated as an alternative strategy for economic development and social reconstruction, especially in less developed countries (Briedenhann \& Wickens 2004). It has also been identified as a catalyst by the United Nations Conference of Trade and Development (UNCTAD 2013), to improve trade and development within regions which, within the African context, can contribute to the African Union's vision of 'an integrated, prosperous and peaceful Africa, driven by its citizens and representing a dynamic force in global arena [sic]' (African Union 2013).

Africa's trade pattern is strongly influenced by its past, with the European Union (EU25) and the United States (US) being the continent's main trade partners. The African Development Bank Group (AFDB 2016) states that, during 2014, the combined imports from the US and EU25 (54.3\%) and exports (46.7\%) to the US and EU25 still represented the majority of trade for Africa, while intra-African trade (exports plus imports) constituted only $18 \%$ of total trade. This is in sharp contrast with the dominant role that intra-regional trade plays in other parts of the world, for example in Europe (69\%), Asia (52\%) and North America (50\%), as estimated by the World Economic Forum (WEF 2016). The following reasons were identified as impacting negatively on intra-regional trade in Africa: high transaction costs, complicated immigration procedures, the limited capacity of border officials, costly import and export policy procedures and a lack of investment in trade associations. These factors not only have a negative effect on regional trade, but also influence regional tourism. Africa's traditional trade partners, usually ex-colonial powers, are being replaced by emerging trade partners like China. In recent times, China has made significant investments into Africa by means of trade, specifically imports. It is estimated that imports from China to South Africa (BRICS) are now exceeding US $\$ 15$ billion or 19\%, followed by Germany (12\%) and a mere 6.7\% from the USA (Trading Economics 2019).

Contrary to trade between African countries, tourism flows between African countries dominate African outbound tourism. The International Air Travel Association (IATA 2014) accounts for 3\% 
of the global air service market, with intra-African tourism, which refers to the tourism activity between various African countries, constituting 70\% of total African air service. The United Nations World Tourism Organization (UNWTO 2013) supports this by stating that $3 \%$ of outbound African markets travel internationally. The main recipients of African tourists by air include: South Africa, Nigeria, Namibia, Kenya and Angola (IATA 2014).

A review of the literature reveals that there is a growing body of research on African tourism, which necessitates an investigation into the drivers of intra-African tourism - the main destination of African travellers. In 2005, Naudé \& Saayman investigated inbound tourism to Africa from various continents using a demand specification and panel data. In 2008, Kareem also used a panel data approach to estimate the determinants of aggregate demand for Africa as a destination, also using a demand-driven specification. In 2012, Du Toit and Fourie investigated which African countries have a comparative advantage in tourism and the sources of the advantage. Fourie and Santana-Gallego (2013) investigated tourism to Africa using a gravity model specification, while more recently Viljoen, Saayman and Saayman (2018) investigated inbound tourism to different African regions.

Most of the available research only focuses on arrivals to Africa, excluding African arrivals, with the research by Naudé and Saayman (2005) and Fourie and Santana-Gallego (2013) the only exceptions, and no research to date explores the determinants of intra-African tourism comprehensively. Research by Saayman and Saayman (2012) leads one to believe that there might be other reasons why Africans travel to other African countries. They show that African tourism to South Africa is driven by shopping tourism, which indicates that the traditional pull factors (sun, sea and sand) may not necessarily apply to intra-African travel and Fourie and Santana-Gallego (2013) confirm this.

Another approach is therefore required and research by Santana-Gallego et al. (2010), Keum (2010), Du Toit and Fourie (2012) signalled an alternative. All these authors applied the principles of trade theory in explaining tourism flows, with Santana-Gallego et al. (2010) using the gravity model, Keum (2010) applying both the gravity model and Linder's hypothesis and Du Toit and Fourie (2012) exploring which African countries have a revealed comparative advantage in tourism and why. The authors mentioned have pioneered the work to use trade theory as a means to explain tourism flows. The aim of this article is therefore to determine whether trade theory is able to explain intraAfrican tourism patterns.

This evaluation is important not only for tourism development on the continent, but also for regional trade facilitation within an intra-regional context (Njoloma 2010:17). In addition, projections indicate that improved cross-border policies could eradicate Africa's 400 million unemployed youth (15 to 35 years of age), while increasing global competitiveness and decreasing reliance on Western economies (World Bank 2012). The remainder of this article is structured as follows: the next section explores the underlying trade theory on which the analysis of intra-African tourism is based. This is followed by a discussion of the data and methods used in the article, before the results of the analysis are presented. Thereafter, the results will be discussed before the article concludes.

\section{Literature review}

One of the earliest trade theories, the Ricardian comparative advantage theory, is based on the differences in labour productivity, while the Heckscher-Ohlin model $(\mathrm{H}-\mathrm{O})$ describes the differences based on factor endowments. Both these theories therefore focus on the competitiveness of a country, but from different perspectives. The H-O theory primarily relies on differences in country endowments to explain the international pattern of trade and production (Debaere \& Demiroglu 2003). The most commonly used analogy includes the ratio between capital and labour. When a country is more capital abundant, it will export capital abundant products, while labour abundant countries will export labour abundant products. The $\mathrm{H}-\mathrm{O}$ model has been applied to many scenarios related to trade, such as demand for skills (Michaels 2008), unemployment reduction (Dutt, Mitra \& Ranjan 2009) and per capita income (Markusen 2013).

Using both these views in tourism competitiveness implies an analysis of the comparative advantage of destinations, as well as the factor endowments. The Balassa index (Balassa 1965) computes the revealed comparative advantage as:

$R C A_{i j}=\frac{x_{i j} / \Sigma_{i} x_{i j}}{\Sigma_{j} x_{i j} / \Sigma_{i} \Sigma_{j} x_{i j}}$

[Eqn 1]

$x_{i j}$ represents exports of sector $i$ from country $j$ (Du Toit, Fourie \& Trew 2010). However, according to Du Toit et al. (2010), more precise and consistent comparisons across time, countries and commodities can be made when another method of measurement is used, that is, the normalised revealed comparative advantage (NRCA), which is computed as:

$N R C A_{i j}=\frac{x_{i j}}{\sum_{i} \Sigma_{j} x_{i j}}-\frac{\left(\Sigma_{i} x_{i j}\right)\left(\Sigma_{j} x_{i j}\right)}{\left(\Sigma_{i} \Sigma_{j} x_{i j}\right)^{2}}$

To test the theory for travel service exports, Du Toit et al. (2010) hypothesised cross-country differences to reveal comparative advantage as a function of relative resource endowments following the $\mathrm{H}-\mathrm{O}$ hypothesis. For example, for country $i$, the comparative advantage in good $j$ is determined by capital $\left(K_{i}\right)$, labour $\left(L_{i}\right)$, natural environment $\left(N_{i}\right)$ and a collection of other possible sources $\left(R_{i}\right)$,such that:

$N R C A_{j}=F\left(K_{i}, L_{i}, N_{i}, R_{i}\right)$

[Eqn 3]

Africa is well known for its natural beauty as a drawcard for international tourists. Therefore, the natural resource endowments $\left(N_{i}\right)$, including aspects such as natural and 
cultural heritage sites (Du Toit \& Fourie 2012), may be the most pertinent for the possible application of the augmented $\mathrm{H}-\mathrm{O}$ theory in tourism.

Following the earlier theories of trade, which focused mainly on the production or supply side of the economy, more recent trade theories turned to evaluating trade from a demand perspective. Linder's country similarity model (1961) is driven by two assumptions. Firstly, countries will export products that are popular in the domestic market, as manufacturers introduce new products to serve the domestic market so that economies of scale are reached and costs are reduced. Secondly, the exported product will be marketed to countries with similar tastes and income levels. Linder (1961) states that the framework for the theory is based on understanding which forces contribute to international or inter-regional specialisation and trade patterns. Linder (1961) indicates that, due to real-world trade, the patterns of trade could be: (1) to some extent accidental, (2) not particularly unstable and (3) gradually changing over time. The theory provides insight into potential trade as many variables have an influence on actual trade such as the distance factor, transport costs and human-made obstacles (tariffs) that are trade-braking forces (Linder 1961). Linder (1961) continues that potential trade between countries with similar demand structures (income per capita) would be most intensive.

The basic assumption of the gravity model is that a country will experience a higher degree of trade with another country sharing common characteristics. A shorter distance, both geographically and culturally, based on similar language, currency, colonial connections and political history enhances trade. Moreover, if the country is rich in resources, as well as being geographically large, enhanced trade will occur compared to countries that do not share the same characteristics (Ciuriak \& Kinjo 2006). The popularity is due to the opportunity to project bilateral trade (Egger 2002). The model was developed using Newton's gravitational force theory by Walter Isard in 1954 and introduced by Tinbergen in 1962. The model is based on the following equation (Fry 2015):

$T_{i j}=A \frac{Y_{i} Y_{j}}{D_{i j}}$,

$T$ represents trade flow between two countries ( $i$ and $j$ ), while $Y$ represents the economic mass of two countries, $D$ represents the distance, and $A$ is a constant. Therefore, the gravitational force between two countries can be calculated if the object mass $\left(Y_{i} Y_{j}\right)$ and the distance $\left(D_{i j}\right)$ are known.

The application of the model has been widely used in testing international trade patterns, currency unions and border effects (see Burger, Van Oort \& Linders 2009; Carrère 2006; Westerlund \& Wilhelmsson 2011). The gravity model has also been applied to tourism scenarios such as transport infrastructure (Khadaroo \& Seetanah 2008), tourism flows (Keum 2010), tourism demand (Hanafiah \& Harun 2010; Hanafiah, Harun \& Jamaluddin 2010; Leitão 2010; Morley,
Rosselló \& Santana-Gallego 2014), tourism competitiveness (Chang \& Lai 2011; Fourie \& Santana-Gallego 2013; Fourie, Rosselló \& Santana-Gallego 2015; Muhammad \& Andrews 2008; Seetanah, Durbarry \& Ragodoo 2010) and tourism and regional integration (Saayman, Figini \& Cassella 2016). It is therefore the most widely applied trade theoretical model in the tourism literature and will therefore also form the basis for our modelling approach.

\section{Data and methods}

The discussion of the method used in this study focuses on (1) the estimating equation and data used, and (2) the estimation methods.

\section{Estimating equations and data}

The baseline estimating equation used in this study follows a typical gravity model specification that has been applied by Gil-Pareja, Llorca-Vivero and Martínez-Serrano (2007), Priego, Rosselló \& Santana-Gallego (2015), and SantanaGallego, Ledesma-Rodríguez and Pérez-Rodríguez (2016) within the tourism context:

$\ln$ Arrivals $_{i j t}=\beta_{0}+\beta_{1} \ln G D P p c_{i t}+\beta_{2} \ln G D P p c_{j t}+$ $\beta_{3} \ln$ Pop $_{i t}+\beta_{4} \ln$ Pop $_{j t}+\beta_{5} \ln$ Distance $_{i j}+\beta_{6} \ln$ RelPrice $_{i j t}+$ $\beta_{7}$ Com Colony $_{i j}+\beta_{8}$ ComLanguage $_{i j}+\beta_{9}$ ComBorder $_{i j}+$ $\gamma_{i}+\delta_{j}+\lambda_{t}+\varepsilon_{i j t}$

Arrivals $_{i j t}$ refers to the number of tourist arrivals from origin country $j$, to destination country $i$ in year $t$ (sourced from the UNWTO, available on request only from the UNWTO), and $\ln$ indicates that natural logarithms of the data are used to ensure linearity of the estimated $\beta^{\prime}$ s. Included in this equation are two measures for mass, namely the gross domestic product (GDP) per capita of the origin and destination countries in constant US dollars as well as the population size of the origin and destination countries sourced from the World Bank Development Indicators (WBDI). Furthermore, the distance between the countries is sourced from the Centre d'Etudes Prospectives et d'Informations Internationales (CEPII, available online: http://www.cepii.fr/cepii/en/ bdd_modele/bdd.asp) as well as the relative price differences between the destination and origin countries defined as the relative CPI ratio (sourced from the WBDI, available online: https://datacatalog.worldbank.org/dataset/worlddevelopment-indicators).

Cultural proximity between the origin and destination country is controlled by using two variables, namely common coloniser and common language (both from CEPII). The former is a dummy variable that takes the value of unity when the countries in question had a common coloniser. The second is also a dummy variable that controls for common ethnic languages spoken in both the origin and the destination country. These variables are associated with stronger social ties between countries, and the expected effect is therefore positive on tourism arrivals between the two countries (Saayman et al. 2016). 
Similarly, the typical gravity model controls for common borders, with a dummy variable that takes the value of one when countries share a common border (obtained from CEPII). To control for unobserved heterogeneity, countryspecific and year-specific fixed effects are included in the estimation, denoted by $\gamma_{i^{\prime}} \varepsilon_{j}$ and $\lambda_{t}$. Finally, $\varepsilon_{i j t}$ represents a well-behaved error term.

This model is referred to as the least-square dummy variable (LSDV) model and is a special case of the panel fixed effect model. The model includes destination and origin dummy variables separately, and therefore it does not control for factors that are common in both countries. The exclusion of bilateral factors that may influence the model is referred to as omitted variable bias. In gravity models, three alternative methods are available in dealing with omitted variable bias, namely: (1) country-pair fixed effects, (2) country-year fixed effects or (3) a multilateral resistance term (Gil-Pareja et al. 2014). In this research, the multilateral resistance term (MRT), introduced by Anderson and Van Wincoop (2003), is included to control for omitted variable bias. It is a bilateral trade cost measure that is unique to each country and is compiled as follows (Saayman et al. 2016):

$$
M R T_{i t}=\sum \frac{\frac{\text { distance }_{i j}}{G D P_{j t}}}{G D P_{\text {world }, t}}
$$

The baseline model is therefore expanded to include the MRT:

$\ln$ Arrivals $_{i j t}=\beta_{0}+\beta_{1} \ln G D P p c_{i t}+\beta_{2} \ln G D P p c_{j t}+$ $\beta_{3} \ln$ Pop $_{i t}+\beta_{4} \ln$ Pop $_{j t}+\beta_{5} \ln$ Distance $_{i j}+\beta_{6} \ln$ RelPrice $_{i j t}+$ $\beta_{7} M_{\text {RT }}+\beta_{8}$ ComColony $_{i j}+\beta_{9}$ ComLanguage $_{i j}+$ $\beta_{10}$ ComBorder $_{i j}+\gamma_{i}+\delta_{j}+\lambda_{t}+\varepsilon_{i j t}$

This specification of the model, therefore, tests the gravity theory and it is expected that the variables measuring mass, that is, population and GDP per capita, will all have positive signs, while the distance variable and the MRT will have negative signs.

The gravity specification above was also expanded to test for (1) Linder's hypothesis, (2) Ricardian comparative advantage theory and (3) the Heckscher-Ohlin resource endowment theory. For Linder's hypothesis, the research by Keum (2010) and Lorde, Li and Airey (2015) was followed in compiling a Linder variable. According to these authors, Linder's hypothesis can be modelled in two ways: (1) the absolute value of the difference between the two countries' GDP per capita (called Linder 1) and (2) the absolute value compiled in (1), but as a ratio of the sum of the GDP per capita of the origin and destination countries (Linder 2):

$$
\begin{aligned}
& \operatorname{Linder}_{i j t}=\left|G D P p c_{i t}-G D P p c_{j t}\right| \\
& \operatorname{Linder}_{i j t}=\frac{\left|G D P p c_{i t}-G D P p c_{j t}\right|}{\left(G D P p c_{i t}+G D P p c_{j t}\right)}
\end{aligned}
$$

The data was obtained from the WBDI. Within the African context, it may be argued that GDP per capita is not the only variable to consider when country similarities in taste and preferences are evaluated. Therefore, this research also considered differences in the urbanisation rate between African countries as a possible variable that may indicate similarities in taste and preferences between countries. These variables were compiled similarly to the Linder variables above, using the urbanisation rate (also available from the WBDI) rather than GDP per capita:

$$
\begin{aligned}
& \text { Linder }_{i j t}=\mid \text { Urbanisation }_{i t}-\text { Urbanisation }_{j t} \mid \\
& \text { Linder }_{i j t}=\frac{\mid \text { Urbanisation }_{i t}-\text { Urbanisation }_{j t} \mid}{\left(\text { Urbanisation }_{i t}+\text { Urbanisation }_{j t}\right)}
\end{aligned}
$$

In all instances, the sign was expected to be negative, since a smaller difference in GDP per capita or urbanisation rates had been associated with increased tourism between the two countries in question. Apart from the inclusion of the Linder variables, the gravity model was also expanded to include Ricardian comparative advantages. The revealed comparative advantage (RCA) and normalised RCA (NRCA) variables were constructed as indicated in Equations 1 and 2. Both of these were also included separately into the gravity specification to test for significance to explain tourism flows in Africa. In general, these terms were expected to relate positively to tourist arrivals.

Finally, the Heckscher-Ohlin theory was tested through the construction of factor endowment differences between countries. Firstly, since tourism is a labour-intensive sector, the ratio between the destination and origin population was considered (referred to as pop_difference in the models). Secondly, differences in natural resource endowment, on which tourism depends, were considered through the calculation of two proxies, namely the ratio of marine protected areas between the destination and origin country (marine_difference in models), and the ratio of terrestrial protected areas between the destination and the origin countries (terra_difference in models). Data for these variables was obtained from the WBDI. It was expected that a larger ratio of endowments would lead to increased tourism flow and therefore a positive sign was expected. The data is summarised in Table 1.

The data set consists of $25^{1}$ African countries' bilateral tourism flows for a period of 10 years (from 2001 to 2010). This provided a panel of 6000 observations. However, tourist arrivals data is not always captured for all countries, given that only the main origin countries are listed separately in the arrivals statistics. The remaining arrivals are often categorised as 'other African countries'. This created some zeros in the arrivals data, which may indicate either zero arrivals, or very low arrival numbers (not significant enough to list separately). Altogether, 3500 of the arrivals data was

1.Algeria; Egypt; Morocco; Tunisia; Burundi; Ethiopia; Kenya; Mauritius; Seychelles Tanzania; Uganda; Benin; The Gambia; Niger; Nigeria; Sierra Leone; Angola; Centra Tanzania; Uganda; Benin; The Gambia; Niger; Nigeria; Sierra Leone; Angola; Central
African Republic; Zambia; South Africa; Lesotho; Madagascar; Malawi; Mozambique; African Repu 
TABLE 1: Results of the gravity model.

\begin{tabular}{|c|c|c|c|c|}
\hline \multirow[t]{2}{*}{ Variable } & \multicolumn{2}{|r|}{ (1) } & \multicolumn{2}{|r|}{ (2) } \\
\hline & LSDV & Standard error & PPML & Standard error \\
\hline _cons & $-39.78 * *$ & 14.46 & 6.395 & 32.53 \\
\hline InGdppc_destination & $0.836 * * *$ & 0.251 & $2.142 * * *$ & 0.510 \\
\hline InGdppc_origin & 0.0758 & 0.284 & 0.103 & 0.518 \\
\hline InPop_destination & $3.123 * * *$ & 0.732 & -0.414 & 2.337 \\
\hline InPop_origin & 0.0967 & 0.292 & 0.279 & 0.517 \\
\hline InRelPrice & -0.129 & 0.116 & -0.0388 & 0.215 \\
\hline InDistance & $-2.080^{* * *}$ & 0.239 & $-2.262 * * *$ & 0.383 \\
\hline MRT & $-4.17 e-10$ & $6.09 \mathrm{e}-10$ & $-1.29 e-09$ & $9.91 \mathrm{e}-10$ \\
\hline ComBorder & $1.457 * * *$ & 0.419 & $1.385^{* *}$ & 0.536 \\
\hline ComLanguage & $0.956 * * *$ & 0.182 & 0.0741 & 0.285 \\
\hline ComColony & $0.0026 * * *$ & 0.0004 & $0.0026 * * *$ & 0.0004 \\
\hline$N$ & 2280 & - & 5300 & - \\
\hline$R$-squared & 0.856 & - & 0.948 & - \\
\hline
\end{tabular}

LSDV, least-square dummy variable; PPML, Poisson pseudo-maximum likelihood; MRT multilateral resistance term.

$* *, p<0.01 ; * * *, p<0.001$.

zero in the panel, which significantly reduces the panel when estimation methods that do not control for missing observations were used.

\section{Estimating methods}

The gravity model is estimated using the LSDV method (which is similar to the fixed effect method) that allows the constant or intercept to differ for each cross-section by introducing a dummy variable for each country. This differs from random effects, which assume that differences between cross-sections are not fixed, but random. With random effects, the intercept is estimated as a constant together with a random variable (Asteriou \& Hall 2016). To ensure that the correct specification is used, the Hausman test was conducted. The chi-square statistic was 36.91, and the null hypothesis can be rejected with $99 \%$ certainty $\left(\chi^{2}=36.91\right.$, $p=0.0013)$. Therefore, the null hypothesis, stating that random effects are consistent and efficient, was rejected, and the remainder of the models were estimated by applying fixed effects (or the LSDV estimator).

The occurrence of zero tourism flows presents problems for log-linear estimations, and it is recommended that procedures such as the Heckman two-step estimation and the Poisson pseudo-maximum likelihood (PPML) estimation should be used to deal with the zero trade matrix to achieve unbiased and consistent estimations (Cipollina \& Salvatici 2010). The PPML method was applied in this research as it addressed the two broad dimensions of problems with gravity model estimation. The first dimension is concerned with the error term, while the second focuses on the degree of model structure. The PPML method is preferred for its robustness in identifying patterns of heteroscedasticity (first dimension errors) and measurement errors (second dimension errors) (Fally 2015:76).

The PPML estimator therefore provides consistent estimations of the original non-linear model with various beneficial properties, for instance: (1) consistency in the presence of fixed effects (entered as dummy variables in OLS), (2) inclusion of observable tourism values that are zero (which is dropped from log-linear OLS models), (3) interpretation is closely related to OLS; however, the dependent variables in PPML are specified in levels rather than logarithms, while the independent variables are still considered as elasticities (United Nations Economic and Social Commission for Asia and the Pacific 2013). Silva and Tenreyro (2006) show that the distance coefficient is smaller when estimating gravity models by applying PPML compared to the LSDV approach. In this research study, all estimations were done using STATA 14 (StataCorp, 2016).

\section{Ethical consideration}

This article followed all ethical standards for carrying out research without direct contact with human or animal subjects.

\section{Results}

The results of the trade models - that is, the gravity model, Linder's model, RCAs, and H-O model - are subsequently discussed.

\section{Gravity model results}

The gravity model, as specified in Equation 5, was estimated by applying the LSDV approach as well as PPML. With the LSDV approach, the regression was estimated by means of OLS, but included both country fixed effects and year fixed effects. The 'robust' estimation option was also chosen for more robust standard errors. Therefore, the LSDV estimates included all the variables involved in the fixed effect estimation, but also other dummy variables that cannot be estimated through fixed effects. These variables included the cultural and physical proximity dummies specified in Equation 5. The results are indicated in column 1 of Table 1. Furthermore, the robustness of the LSDV estimation was also tested using the PPML estimator (country and year dummy variables were also included in the PPML estimations to control for country differences and business cycle effects). The results are indicated in column 2 of Table 1.

It is evident from Table 1 that the $R$-squared was very high with more than $85 \%$ of the variance explained, as is typical of gravity models. It is also noteworthy that the LSDV estimator uses fewer observations $(\mathrm{N})$ due to the zeros in the tourist arrivals data. This is corrected in the PPML estimations (compare 2280 to 5300 observations), which control for zero observations. Because the PPML estimates include the zeros in the estimation, the results differ slightly from those of the LSDV approach. However, it is encouraging to see that although the parameter estimates differ slightly, the nature of the relationship (positive or negative) is not influenced by the estimation method.

In general, the results of the gravity model are in line with theory, that is, the mass variables, GDP per capita and total population are positive although only the destination 
variables are significant. The distance variable is negative and significant in all the estimated results. This confirms the gravity model in explaining tourism flows within the African continent. The results were quite robust and did not change significantly when more dummy variables were added ${ }^{2}$ or when the PPML estimator was utilised.

Concerning the other variables, it is evident that the relative price variable is negative in all specifications, but insignificant. The MRT is also very small and insignificant in explaining tourism flows. The dummy variables indicate that sharing a common border has a strong positive and significant influence on tourism between the origin and destination country. Likewise, cultural proximity is clearly a significant determinant of tourism, with common ethnic language being positive and significant in the LSDV estimation. The influence of colonisation is also very clear with countries that used to be colonised by the same country experiencing enhanced tourism flows between one another.

The results compare well with findings by Keum (2010:555), who states that the distance and the economic size between origin and destination are the most important variables for the gravity model. This is confirmed by Lorde et al. (2015:8) specifying that destination and origin income, destination population and substitute prices are important variables. This also confirms that the gravity model does well in explaining intra-Africa tourism flows. It shows that larger economies in population size, as well as richer economies (in GDP per capita) attract more tourists than smaller and poorer economies do. Distance plays a key role, and African tourists tend to travel more to neighbouring countries, countries that were colonised by the same country and where the ethnic language is similar to their own.

\section{Linder's hypothesis results}

To test whether Linder's hypothesis can be used to explain intra-Africa tourism, the same gravity model, specified in Equation 5, was used and the various Linder variables (specified in Equations 8-11) were included separately. The results are indicated in Table 2 . The first four columns (1 to 4 ) of Table 2 indicate the results of the LSDV estimations and the last four columns (5 to 8) the PPML estimations.

In general, the results of the models in Table 2 echo those of Table 1, with destination GDP per capita being positive and significant, and distance negative and significant in all estimations. The dummy variables - common border, common ethnic language and common coloniser - are also still significant in explaining intra-African tourism flows. These variables indicate a reduction in cultural distance, which is associated with increased tourism arrivals (SantaGallego et al. 2016).

Concerning the Linder variables, it is evident that all the Linder variables are insignificant, except for the PPML estimation with the ratio of the difference between the 2.More detailed results available from the authors on request

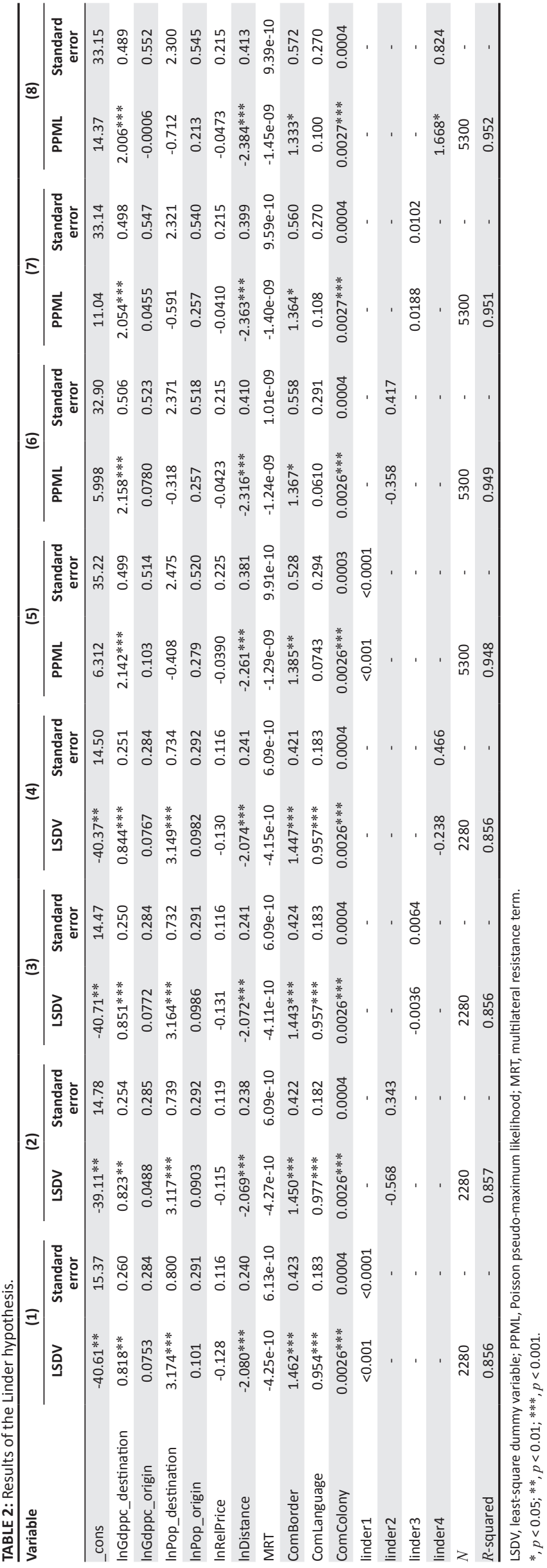


urbanisation rates relative to the sum of the urbanisation rate between the origin and destination country. In this instance, the variable is positive and significant at a $5 \%$ level. This is contrary to Linder's theory, which predicts that countries with similar characteristics (smaller Linder variables) will trade more with one another (travel more to one another). Moreover, Lorde et al. (2015) also found that the Linder variable had an inverse effect on the level of tourism flow relating to per capita consumption and income levels in Caribbean countries. However, the similarity between the origin countries' income and the income of the Caribbean region shows a convergence, which might have had an influence on the results. This cannot, however, be used as an explanation within the African context.

Since Linder 1 and Linder 2 are positive, it indicates that large differences exist between countries' demand characteristics and tourism arrivals (Keum 2010). This is also supported by the positive and significant Linder 4 , which addresses the absolute value of urbanisation as a ratio of the sum of urbanisation rate. It indicates that less urbanised countries tend to travel to more urbanised countries, and vice versa. Both Keum (2010) and Lorde et al. (2015) revealed that Linder's hypothesis does not explain tourism flows, and this study confirms the same results for Africa.

\section{Revealed comparative advantage results}

The RCA and NRCA for every African country were calculated according to Equation 1 and Equation 2. The calculation involved using tourism receipts and export data from the WBDI database. It therefore represents not only African receipts from tourism, but total tourism receipts from all international tourist arrivals. Table 3 presents the results for the gravity model specification augmented with the RCA and the NRCA separately.

The results in Table 3 confirm the results of the previous models in terms of the gravity specification, with destination GDP per capita and population variables as positive and significant determinants of tourism arrivals. The distance result is again negatively related to tourism arrivals, while the common country characteristics were positive and significant, similar to the previous modelling results.

The RCA is positive, as expected, but insignificant, while the NRCA is positive and significant for both least-square dummy variable (LDSV) and PPML estimations. The RCA results imply that countries that show an RCA for worldwide tourism receipts also benefit most from African tourism. However, the NRCA results indicate that the combination of capital, labour, natural resources and other resources has a positive and significant influence on arrivals, especially when the model is estimated using LSDV. This implies that countries endowed with more natural resources will increase the relative or comparative advantage in exporting tourism services, because NRCA is a function of capital, labour, natural environment and a collection of vectors of other possible sources (Du Toit et al. 2010:8). To explore this in more detail, the next set of results reports the $\mathrm{H}-\mathrm{O}$ variables.

\section{The Heckscher-Ohlin results}

The $\mathrm{H}-\mathrm{O}$ variables are calculated using the factor endowment differences between countries. For every destination and origin country population difference (as a proxy for available labour work force), pop_difference, is determined. For the differences in natural resource endowments between destination and origin country, both the terrestrial protected area and marine protected area between the two countries, specified as terra_difference and marine_difference, are used. These variables were included in the basic gravity specification and the results are shown in Table 4.

The results in Table 4 show that the basic gravity variables are still significant, especially with regard to GDP per capita, population, distance and common characteristics. The inclusion of the $\mathrm{H}-\mathrm{O}$ variables therefore does not influence the main gravity results, indicating robustness. Differences in

TABLE 3: Revealed comparative advantage results.

\begin{tabular}{|c|c|c|c|c|c|c|c|c|}
\hline \multirow[t]{2}{*}{ Variable } & \multicolumn{2}{|c|}{ (1) } & \multicolumn{2}{|c|}{ (2) } & \multicolumn{2}{|c|}{ (3) } & \multicolumn{2}{|c|}{ (4) } \\
\hline & LSDV & Standard error & LSDV & Standard error & PPML & Standard error & PPML & Standard error \\
\hline _cons & $-39.77 * *$ & 14.42 & $-51.29 * * *$ & 14.16 & 6.935 & 34.49 & 5.835 & 32.45 \\
\hline InGdppc_destination & $0.880 * * *$ & 0.252 & $1.010 * * *$ & 0.251 & $2.172 * * *$ & 0.501 & $2.135 * * *$ & 0.479 \\
\hline InGdppc_origin & 0.0801 & 0.283 & 0.171 & 0.274 & 0.114 & 0.504 & 0.229 & 0.476 \\
\hline InPop_destination & $3.092 * * *$ & 0.734 & $3.201 * * *$ & 0.726 & -0.500 & 2.461 & -0.605 & 2.301 \\
\hline InPop_origin & 0.101 & 0.291 & 0.192 & 0.282 & 0.289 & 0.501 & 0.406 & 0.473 \\
\hline InRelPrice & -0.129 & 0.116 & -0.0560 & 0.121 & -0.0511 & 0.207 & 0.0304 & 0.189 \\
\hline InDistance & $-2.080 * * *$ & 0.240 & $-2.077 * * *$ & 0.239 & $-2.261 * * *$ & 0.383 & $-2.261 * * *$ & 0.383 \\
\hline MRT & $-4.03 e-10$ & $6.09 e-10$ & $1.41 \mathrm{e}-09$ & $7.27 e-10$ & $-1.07 e-09$ & $1.01 \mathrm{e}-09$ & $-3.51 e-10$ & $1.07 e-09$ \\
\hline ComBorder & $1.457 * * *$ & 0.419 & $1.459 * * *$ & 0.418 & $1.385 * *$ & 0.536 & $1.385 * *$ & 0.536 \\
\hline ComLanguage & $0.956 * * *$ & 0.182 & $0.951 * * *$ & 0.182 & 0.0742 & 0.285 & 0.0739 & 0.285 \\
\hline ComColony & $0.00266 * * *$ & 0.0004 & $0.00266 * * *$ & 0.0004 & $0.00261 * * *$ & 0.0004 & $0.00261 * * *$ & 0.0004 \\
\hline RCA & 0.0322 & 0.0353 & - & - & 0.106 & 0.0636 & - & - \\
\hline NRCA & - & - & $2351.4 * * *$ & 523.4 & - & - & $797.4^{*}$ & 401.4 \\
\hline$N$ & 2280 & - & 2280 & - & 5300 & - & 5300 & - \\
\hline$R$-squared & 0.856 & - & 0.856 & - & 0.950 & - & 0.950 & - \\
\hline
\end{tabular}

LSDV, least-square dummy variable; PPML, Poisson pseudo-maximum likelihood; MRT, multilateral resistance term.

$*, p<0.05 ; * *, p<0.01 ; * * *, p<0.001$. 


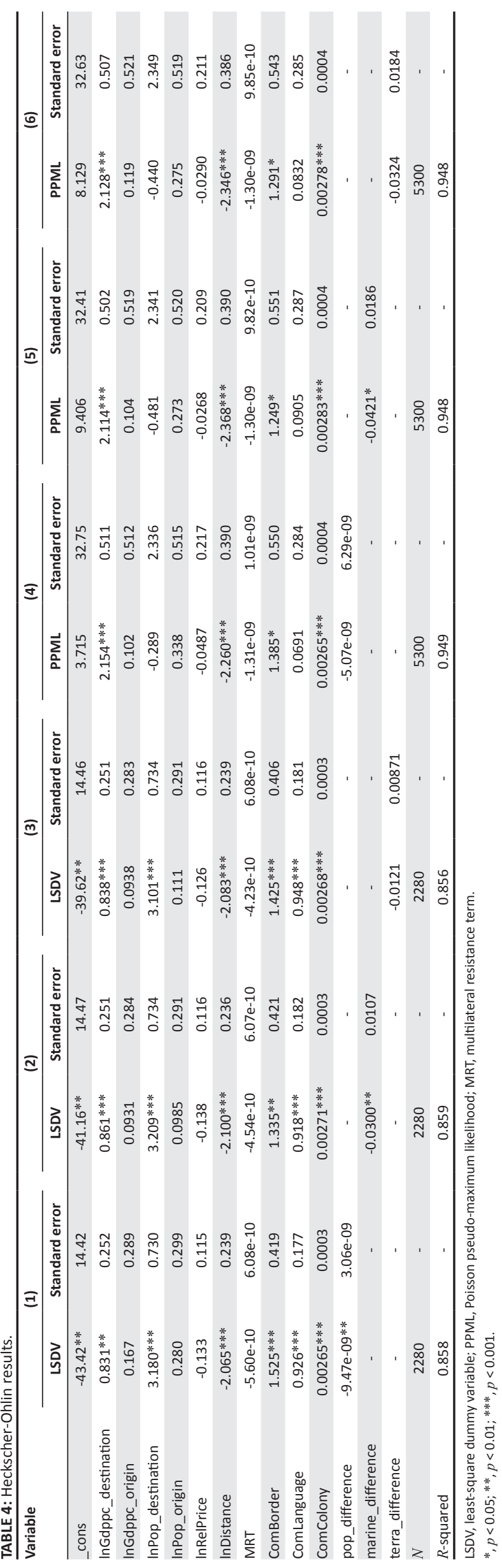

factor endowments, expressed as population differences (pop_difference), ratio of marine protected areas (marine difference) and ratio of terrestrial protected areas (terra difference) were included separately in the estimations.

A larger difference implies large differences in endowments and therefore a positive sign was expected, which would signify increased tourism flows. The results indicate that terra_difference in the LSDV estimation is positive, but not significant, and negative in the PPML estimation. The remaining variables (pop_difference and marine_difference) are both negative, but pop_difference is significant in LSDV, and marine_difference is significant in both estimations. The results are contrary to expectations and indicate that tourism resource endowment may not be a driver for intra-African tourism. This confirms the notion that African tourists' travel patterns are less reliant on natural tourism resources of other African countries, and by preference more dependent on cultural and geographical proximity as well as the development of the destination country.

\section{Discussion}

Does trade theory explain intra-African tourism patterns? The results from the analyses do indeed suggest that tourism flows in Africa follow the predictions of trade theoretical models. More specifically, intra-African tourism is consistent with the predictions of the gravity model and there is also some support for specialisation in tourism, as indicated by the revealed comparative advantage theory.

The following findings and implications are based on the research results: firstly, the gravity model offers a robust explanation for tourism patterns in Africa. The results show that larger and more developed African destinations (measured by total population and GDP per capita) benefit most from African tourism. This result can be explained when the research by Saayman and Saayman (2012) on African tourism to South Africa is considered, which indicates that a large portion of African travel is for shopping purposes. Larger, more developed countries offer access to goods and services that cannot be found in the African traveller's home country.

The gravity model results also show that distance between countries plays a key role, with African tourists preferring to travel to destinations closer to their own country. This result is also evident in the significance of the common border dummy variable in all the specifications. The reasons African travellers choose closer destinations may be influenced by (1) travel cost in Africa and (2) accessibility of African countries for African travellers; for example, two-thirds of Africans travelling within Africa are obligated to apply for visas (AFDB 2014:10).

The third finding from the gravity model results is that decreased cultural distance between countries, as measured by the common ethnic language and common coloniser 
dummy variables, contributed to increased arrivals. Regional economic integration could possibly lead to enhanced competitiveness, prevent conflicts and consolidate economic and social reforms. This is especially true for countries that share common ethnic languages, a common coloniser or common borders, as the cultural distance is not a deterrent. The higher degree of integration makes it possible for trade and tourism to flourish, and subsequently leads to enhanced economic activity and growth for the region.

Linder's hypothesis implies that countries with similar demand structures will trade more with and travel more to one another. However, the results for intra-African tourism do not confirm this notion. They indicate that countries with different demand structures experience increased tourism flows. Larger African economies that are better developed and more urbanised attract more African arrivals. This result again confirms the notion by Saayman and Saayman (2012) that African tourists travel predominantly for shopping purposes. The insignificance of most of the Linder variables also confirms research by Keum (2010), who found that Linder's model also does not explain Asian travel patterns.

The results of the RCA and NRCA indicate that countries that have a RCA in tourism, that is, ratio of tourism export receipts compared to total export receipts, are not only benefiting from international tourism, but are also more popular destinations for African tourists. These tourismoriented countries are successful due to the existing tourism infrastructure, which shows the importance of a clear focus on tourism development. However, while Du Toit and Fourie (2010) found that the RCA is mainly because of the natural and cultural heritage of various African countries, the $\mathrm{H}-\mathrm{O}$ results in this study show that resource endowment differences (terra_difference and marine_difference) between African countries do not dictate African tourism flows. In fact, tourism flows are greater for countries with similar tourism resources. This again highlights that a large portion of African travel is not driven by typical tourism attractions, such as sightseeing, sun, sea, sand or safaris.

\section{Conclusion}

Intra-African travel has, to date, received little empirical investigation, although the majority of African outbound travel is to other African countries. The continent is therefore the main destination for African tourists. Since African tourism does not seem to follow the same trends as international travel does, the aim of this article was to determine whether trade theory is able to explain intraAfrican tourism patterns.

Using bilateral tourism flows from 25 African countries over a 10-year period, this research shows that African tourism flows are consistent with the gravity theory. This implies that distance is a key determinant of African tourism, as well as the size and level of development of the destination and the cultural proximity of the origin and destination countries. Little support could be found for the statistical significance of the other trade theories in explaining African travel patterns.

This research contributes to a greater understanding of the determinants that attract African travellers to other African countries. It is clear that the reasons international tourists travel to Africa - for safari, culture, sun, sea and sand - are not the main driving forces of intra-African tourism. The results rather indicate that African tourists travel more to larger, developed African countries that are close to their country (in the geographical as well as the cultural sense) and therefore the notion that a large portion of African travel is for shopping purposes is supported.

This holds important implications for policymakers as well as tourism destination managers. Policies to promote inter-regional travel and movement of goods (i.e. regional economic integration) would therefore facilitate tourism growth. This implies improved accessibility in terms of lower visa restrictions as well as better transport infrastructure. It is also important for tourism destination managers to recognise that African tourists travelling to their countries are from countries with similar tourism resources (protected and marine areas) and would therefore not necessarily be interested in these tourism products. The preference might therefore be for more urban tourism products.

While the research explored intra-African tourism, future research should expand the model to include a more comprehensive set of countries, including non-African countries, and to distinguish between different reasons for travel, such as visiting friends and family, business or holiday. Furthermore, it would be worthwhile to determine the effect that different types of trade agreements in Africa have on bilateral tourism flows.

\section{Acknowledgements}

The authors would like to thank the United Nations World Tourism Organization for granting access to the travel data used in this article.

\section{Competing interests}

The authors have declared that no competing interest exist.

\section{Author's contributions}

A.H.V. was responsible for overall article layout, literature review and discussion. A.S. analysed the data and was the primary contributor to the methodology. M.S. contributed in terms of the findings and implications.

\section{Funding}

National Research Foundation South Africa (NRFSA) Freestanding, Innovation and Scarce Skills Masters and Doctoral Scholarship grant programme: 89060/ UID 87497. 


\section{Data availability statement}

Data sharing is not applicable to this article as no new data were created or analysed in this study.

\section{Disclaimer}

The views and opinions expressed in this article are those of the authors and do not necessarily reflect the official policy or position of any affiliated agency of the authors.

\section{References}

African Development Bank Group, 2016, African Economic Outlook 2016, viewed 18 May 2017, from http://www.afdb.org/fileadmin/uploads/afdb/Documents/ Publications/AEO_2016_Report_Full_English.pdf.

African Union, 2013, Vision of the African Union, viewed 15 November 2016, from http://au.int/en/about/nutshell.

Anderson, J.E. \& Van Wincoop, E., 2003, 'Gravity with gravitas: A solution to the border puzzle', The American Economic Review 93(1), 170-192. https://doi.org/ $10.1257 / 000282803321455214$

Asteriou, D. \& Hall, S.G., 2016, Applied econometrics, Palgrave Macmillan, New York.

Balassa, B., 1965, 'Trade liberalisation and "revealed" comparative advantage', The Manchester School 33(2), 99-123. https://doi.org/10.1111/j.1467-9957.1965. tb00050.x

Briedenhann, J. \& Wickens, E., 2004, 'Tourism routes as a tool for the economic development of rural areas - Vibrant hope or impossible dream?', Tourism Management 25(1), 71-79. https://doi.org/10.1016/S0261-5177(03)00063-3

Burger, M., Van Oort, F. \& Linders, G.J., 2009, 'On the specification of the gravity model of trade: Zeros, excess zeros and zero-inflated estimation', Spatial Economic Analysis 4(2), 167-190. https://doi.org/10.1080/17421770902834327

Carrère, C., 2006, 'Revisiting the effects of regional trade agreements on trade flows with proper specification of the gravity model', European Economic Review 50(2), 223-247. https://doi.org/10.1016/j.euroecorev.2004.06.001

Chang, S.C. \& Lai, F.T., 2011, 'Intra-continental and intercontinental service trade in the travel and tourism industry', Tourism Economics 17(5), 963-982. https://doi. org $/ 10.5367 /$ te. 2011.0078

Cipollina, M. \& Salvatici, L., 2010, 'The trade impact of European Union agricultural preferences', Journal of Economic Policy Reform 13(1), 87-106.

Ciuriak, D. \& Kinjo, S., 2006, 'Trade specialization in the gravity model of international trade', in J.M. Curtis \& D. Cuiriak (eds.), Trade policy research (pp. 189-197), Minister of Public Works and Government Services, Quebec.

Debaere, P. \& Demiroglu, U., 2003, 'On the similarity of country endowments', Journal of International Economics 59(1), 101-136. https://doi.org/10.1016/S00221996(02)00092-2

Du Toit, L. \& Fourie, J., 2012, 'Africa's comparative advantage in travel service exports', Studies in Economics and Econometrics 36(1), 1-22.

Du Toit, L., Fourie, J. \& Trew, D., 2010, The sources of comparative advantage in tourism, Working paper (No. 01/2010), Stellenbosch University, Department of Economics, Stellenbosch, viewed 15 June 2016, from www.ekon.sun.ac.za/ wpapers/2010/wp012010/wp-01-2010.pdf.

Dutt, P., Mitra, D. \& Ranjan, P., 2009, 'International trade and unemployment: Theory and cross-national evidence', Journal of International Economics 78(1), 32-44. https://doi.org/10.1016/j.jinteco.2009.02.005

Egger, P., 2002, 'An econometric view on the estimation of gravity models and the calculation of trade potentials', The World Economy 25(2), 297-312. https://doi. org/10.1111/1467-9701.00432

Fally, T., 2015, 'Structural gravity and fixed effects', Journal of International Economics 97(1), 76-85. https://doi.org/10.1016/j.jinteco.2015.05.005

Fourie, J. \& Santana-Gallego, M., 2013, 'The determinants of African tourism' Development Southern Africa 30(3), 347-366. https://doi.org/10.1080/037683 5X.2013.817302

Fourie, J., Rosselló, J. \& Santana-Gallego, M., 2015, 'Religion, religious diversity and tourism', Kyklos 68(1), 51-64. https://doi.org/10.1111/kykl.12066

Fry, R., 2015, International trade, Clanrye International, Jersey City.

Gil-Pareja, S., Llorca-Vivero, R. \& Martínez-Serrano, J.A., 2007, 'The effect of EMU on tourism', Review of International Economics 15(2), 302-312. https://doi.org/ 10.1111/j.1467-9396.2006.00620.x

Hanafiah, M.H., Harun, M.F. \& Jamaluddin, M.R., 2010, 'Bilateral trade and tourism demand', World Applied Sciences Journal 10, 110-114.

Hanafiah, M.H.M. \& Harun, M.F.M., 2010, 'Tourism demand in Malaysia: A crosssectional pool time-series analysis', International Journal of Trade, Economics and Finance 1(1), 80-83. https://doi.org/10.7763/IJTEF.2010.V1.15

International Air Travel Association, 2014, Transforming Intra-African Air Connectivity: The economic benefits of implementing the Yamoussoukro decision, viewed 15 Jun 2016, from https://www.iata.org/whatwedo/Documents/economics/InterVISTAS AfricaLiberalisation_FinalReport_July2014.pdf.
Kareem, O.I., 2007, 'A panel data analysis of demand for tourism in Africa', paper presented at the 12th African Econometric Society Annual Conference, Cape presented at the 12th African
Town, South Africa, 4-6 July.

Keum, K., 2010, 'Tourism flows and trade theory: A panel data analysis with the gravity model', The Annals of Regional Science 44(3), 541-557. https://doi.org/10.1007/ s00168-008-0275-2

Khadaroo, J. \& Seetanah, B., 2008, 'The role of transport infrastructure in international tourism development: A gravity model approach', Tourism Management 29(5), 831-840. https://doi.org/10.1016/j.tourman.2007.09.005

Leitão, N.C., 2010, 'Financial development and economic growth: A panel data approach', Theoretical and Applied Economics 17(10), 15-24.

Linder, S.B., 1961, 'An essay on trade and transformation', Almqvist \& Wiksell, Stockholm.

Lorde, T., Li, G. \& Airey, D., 2015, 'Modeling Caribbean tourism demand: An augmented gravity approach', Journal of Travel Research 1(2015), 1-11.

Markusen, J.R., 2013, 'Putting per-capita income back into trade theory', Journal of International Economics 90(2), 255-265. https://doi.org/10.1016/j.jinteco.2013. 04.003

Michaels, G., 2008, 'The effect of trade on the demand for skill: Evidence from the interstate highway system', The Review of Economics and Statistics 90(4), 683-701. https://doi.org/10.1162/rest.90.4.683

Morley, C., Rosselló, J. \& Santana-Gallego, M., 2014, 'Gravity models for tourism demand: Theory and use', Annals of Tourism Research 48(2014), 1-10. https:// doi.org/10.1016/j.annals.2014.05.008

Muhammad, A. \& Andrews, D., 2008, 'Determining tourist arrivals in Uganda: The impact of distance, trade and origin-specific factors', African Journal of Accounting, Economics, Finance and Banking Research 2(2), 51-62.

Naudé, W. \& Saayman, A., 2005, 'Determinants of tourist arrivals in Africa: a pane data regression analysis', Tourism Economics 11(3), 365-391. doi:105367/000000 005774352962.

Njoloma, E., 2010, 'A study of intra-African relations: An analysis of the factors informing the foreign policy of Malawi towards Zimbabwe', Master's dissertation, Rhodes University.

Priego, F.J., Rosselló, J. \& Santana-Gallego, M., 2015, 'The impact of climate change on domestic tourism: A gravity model for Spain', Regional Environmental Change 15(2), 291-300. https://doi.org/10.1007/s10113-014-0645-5

Saayman, A., Figini, P. \& Cassella, S., 2016, 'The influence of formal trade agreements and informal economic cooperation on international tourism flows', Tourism Economics 22(6), 1274-1300. https://doi.org/10.1177/1354816616672600

Saayman, M. \& Saayman, A., 2012, 'Shopping tourism or tourists shopping? A case study of South Africa's African tourism market', Tourism Economics 18(6), 1313-1329. https://doi.org/10.5367/te.2012.0169

Santana-Gallego, M., Ledesma-Rodríguez, F.J. \& Pérez-Rodríguez, J.V., 2016, 'International trade and tourism flows: An extension of the gravity model', Economic Modelling 52(1), 1026-1033. https://doi.org/10.1016/j.econmod.2015.10.043

Santana-Gallego, M., Ledesma-Rodríguez, F.J., Pérez-Rodríguez, J.V. \& Cortés-Jiménez, I. 2010, 'Does a common currency promote countries' growth via trade and tourism?', The World Economy 33(12), 1811-1835. https://doi.org/10.1111/j.14679701.2010.01305.x

Seetanah, B., Durbarry, R. \& Ragodoo, J.F.N., 2010, 'Using the panel cointegration approach to analyse the determinants of tourism demand in South Africa' Tourism Economics 16(3), 715-729. https://doi.org/10.5367/000000010792278437

Silva, J.S. \& Tenreyro, S., 2006, 'The log of gravity', The Review of Economics and Statistics 88(4), 641-658. https://doi.org/10.1162/rest.88.4.641

StataCorp, 2016, Stata Statistical Software (Release 14) [computer software], StataCorp LP, College Station, TX.

Tinbergen, J., 1962, Shaping the world economy; suggestions for an internationa economic policy. The Twentieth Century Fund, New York.

Trading Economics, 2019, South Africa imports by country, 2017, viewed 23 April 2019, from https://tradingeconomics.com/south-africa/imports-by-country.

United Nations Conference of Trade and Development, 2013, Economic Development in Africa Report 2013: Intra-African Trade: Unlocking private sector dynamism, viewed 05 May 2016, from http://unctad.org/en/PublicationsLibrary/aldcafrica 2013_en.pdf.

United Nations Economic and Social Commission for Asia and the Pacific, 2013 Gravity model report, viewed 05 May 2016, from http://www.unescap.org/sites/ default/files/full-report-gravity-model-2013.pdf.

United Nations World Tourism Organisation, 2013, Tourism highlights, 2013 edn. viewed 05 May 2016, from https://www.e-unwto.org/doi/pdf/10.18111/97892 84415427.

Viljoen, A., Saayman, A. \& Saayman, M., 2018, 'Determinants influencing inbound arrivals to Africa', Tourism Economics (November). https://doi.org/10.1177/13548 16618809840

Westerlund, J. \& Wilhelmsson, F., 2011, 'Estimating the gravity model without gravity using panel data', Applied Economics 43(6), 641-649. https://doi.org/10.1080/ 00036840802599784

World Bank, 2012, Let Africa trade with Africa, viewed 05 May 2016, from http:// www.worldbank.org/en/news/video/2012/02/01/let-africa-trade-with-africa.

World Economic Forum, 2016, Africa needs to trade with itself - Here's how, viewed 18 November 2016, from https://www.weforum.org/agenda/2016/04/africaneeds-to-trade-with-itself/. 